\title{
COPD and tobacco smoke
}

\author{
M. Bartal
}

\section{ABSTRACT: COPD and tobacco smoke. M. Bartal.}

Chronic obstructive pulmonary disease (COPD) is a chronic inflammation of the airways, including the parenchyma and the pulmonary vasculature. The burden of COPD is increasing around the world in terms of morbidity and mortality in adult population. Active smoking is a major risk factor for COPD, although there is individual susceptibility to the effects of tobacco smoke. This variability could result from host as well as environmental factors. Even passive smoking in early childhood as well as intrauterine exposure could pave the way for COPD. Tobacco smoke induces a specific, persistent inflammation, different from that of asthma. Three other processes accompany and interact with inflammation: imbalance of both the proteases-antiproteases, the oxidants-antioxidants, and improper repair mechanisms. These processes respectively lead to mucus hypersecretion and alveol wall destruction, dysfunction and death of biological molecules, damage to the extra- cellular matrix and pulmonary fibrosis with adventitial, submucosal and smooth muscle thickening. The earlier the smoke exposure, the greater the level of decline in lung function. Combined mucus hypersecretion, reduced clearance, and impairment of the lung defence mechanisms explain why COPD patients even with stable condition, carry potential respiratory pathogens in significant concentration, paving the way for infection and acute exacerbations of COPD. Every additional exacerbation in a smoker deteriorate more the lung function. Fortunately, smoking cessation, which is a part of the respiratory rehabilitation could reduce the number of hospitalisations and the decline of lung function, and thus reduce the management cost of the disease and improve the quality of life. The earlier the quitting, the better the improvement of $\mathrm{FEV}_{1}$. "Smoking cessation is the single effective and cost effective way to reduce exposure to COPD risk factors" (GOLD, evidence A). Monaldi Arch Chest Dis 2005; 63: 4, 213-225.

Keywords: Tobacco, smoking, COPD, lung function, smoking cessation.

President of the Moroccan Society of Allergology and Clinical Immunology, Casablanca, Morocco.

Correspondence: Mohamed Bartal; President of the Moroccan Society of Allergology and Clinical Immunology, Casablanca, Morocco; e-mail: bartalmoh@menara.ma

\section{The burden of COPD}

Although underestimated, chronic obstructive pulmonary disease (COPD) is a leading cause of morbidity and mortality worldwide amongst the adult population [1-8]. According to estimates, COPD, which has increased from the $6^{\text {th }}$ most common cause of death worldwide in 1990 to the $5^{\text {th }}$ in 1998 [7], will increase to to $3^{\text {rd }}$ most common cause of death by $2020[4,8]$. When the burden is expressed in disability-adjusted life-years (DALYs), that is the sum of years lost due to premature death and years of life lived with disability adjusted to the severity of disability, COPD was responsible for $2.1 \%$ of DALYs, ranking $12^{\text {th }}$ in 1990 . It is estimated to be the $5^{\text {th }}$ cause in 2020 with $4.1 \%$ of DALYs whereas ischemic heart disease and tuberculosis for instance will be in 1st and the 7th with $5.9 \%$ and $3.1 \%$ of DALYs respectively $[1,9]$ (fig. 1). The prevalence of COPD is underestimated around the world, ranging from 2.70 and $2.80 \%$ in males and females respectively in Middle Eastern Crescent to 26.20 and $23.70 \%$ in China with a mean value in 1990 of 9.34 and $7.33 \%$ (fig. 2). The prevalence of COPD is highest in countries where cigarette smoking is common and rooted in the "traditional way of life", as is the case in many areas of Asia. Recent data from cross-sectional studies in general population from industrialised countries, has shown a prevalence ranging from 3.7 to $11 \%$, depending on both country and methodological differences [10].

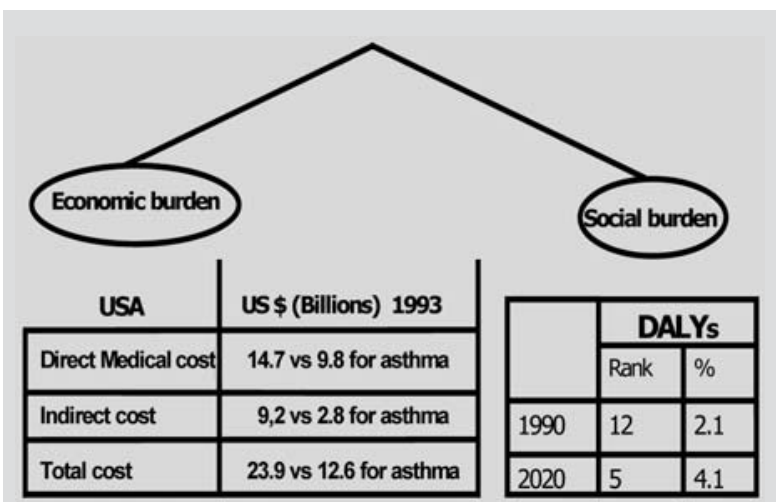

Fig. 1. - The burden of COPD.

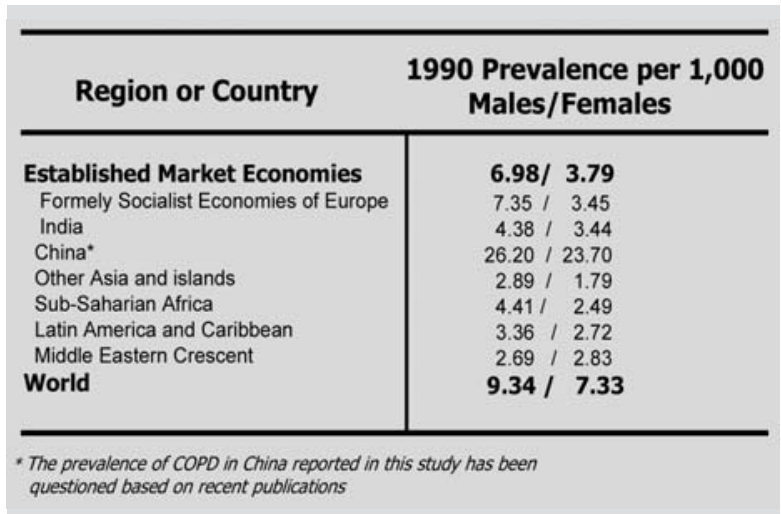

Fig. 2. - Prevalence of COPD around the world (all ages) 
The natural history of COPD is characterised by a progressive, irreversible decline in lung function. Premature mortality after years of suffering dyspnoea and disability is the ultimate outcome of the disease. Fletcher et al. [11] have demonstrated a 10-year survival of $50 \%$ after a clinical diagnosis in patients who continued to smoke, versus $80 \%$ in ex-smokers. In the Seven Countries Study [12], the relative risk of death from any cause within a 15 year follow-up, adjusted for several risk factors including age and smoking, was 1.67 (95\% CI:1.481.88 ) for patients with COPD, with large variability between countries. Age with rapid decline of $\mathrm{FEV}_{1}$ are the strongest predictors of premature death, explaining why the prevalence and the burden of COPD are higher in developed countries where life expectancy is greater than in developing countries [13]. The poorest and less educated section of the population [14] is the most affected in terms of morbidity and mortality, probably because of intricacy of multifactorial risk factors including intrauterine exposure, childhood infection, occupational exposure and the way of life (housing, nutrition, ...) [15]. In low income countries it is expected that an increase in smoking prevalence will lead to future increase in COPD prevalence, theoretically without a predicted increase in health care costs because hospital-based and long-term care are less available or affordable than in high income countries. But in terms of productivity lost, the toll of COPD is very large in low income areas where labour is often the production tool that drives the economies [16]. Developing countries can ill afford the increased social and economic burden of COPD and their smoking-related disorders. Individually, the poorest people pay the highest toll because they can afford neither quitting measures nor appropriate therapy, at least this is the situation in developing countries [17]. Estimated relative risks for COPD mortality among smokers compared to non-smokers range from 2 to 32 , depending on factors such as age, sex, smoking history $[15,18]$. According to the World Health Organisation, approximately $90 \%$ of all health care of COPD in men and $80 \%$ of all costs of COPD in women, are attributable to smoking [7]. It is estimated that between 1994-2015, the increase in the burden of smoking-related COPD will be greater in females than in males, notably in developing countries, with a $142 \%$ and $43 \%$ increase prevalence, respectively $[14,16]$.

\section{Active smoking is a major risk factor for COPD}

Smoking is by far the most important cause of COPD and emphysema [1-2, 11, 18-21] (fig. 3). These diseases might be coined "chronic smoking diseases" as it accounts for 80 to $90 \%$ of the risk in developed countries. But the disorder appears with a 10- to 20-year time lag [22]. To a large extent, the alarming predictions of the burden of COPD reflect the expansion and distribution of smoking. Both cross-sectional and longitudinal studies consistently show that long-term cigarette smoking predisposes to COPD and to higher prevalence of respiratory symptoms, higher risk of decreased $\mathrm{FEV}_{1}[19,23]$ and greater COPD mortality rate than nonsmokers. There is also a strong dose-response relationship between the amount of cigarettes smoked and the rate of decline in $\mathrm{FEV}_{1}$ [24]. All that despite a "healthy smoker effect" [24] which underestimates the real effects of smoking and tends to hide the effects of smoking on spirometry indices. Indeed, may be individuals who take up early and regular smoking are those with good respiratory health. Pipe and cigar smokers have also but in a lower level, a higher COPD morbidity and mortality rate than nonsmokers [25, 26]. Other types of tobacco use, specific to some areas are surely risk factors for COPD, but literature is missing in this regard. It is noteworthy that exposure to vapours, irritants, or fume, particularly in occupational settings, could provoke COPD on their own $[19,27,28]$. Tobacco smoke and such exposure may act additionally to increase the risk of developing COPD [28-30]. Data concerning the wide individual susceptibility which makes smokers with a similar amount of cigarettes unequal towards the risk is extremely important. As a matter of fact, only 15 to $30 \%$ of smokers may develop clinically significant airflow limitation [11] whereas as many as $10 \%$ of non-smokers will develop COPD $[11,31]$. In fact, recent data from Sweden has shown that COPD prevalence in persistent smokers over 75 years of age is $45 \%$ : $60 \%$ in males, $25 \%$ in females, opposed to 20 and $14.5 \%$ respectively in non-smokers of the same age [32]. Fletcher et al. [11] have proposed since 1977 a model of decline of $\mathrm{FEV}_{1}$ over time, coming from the first large-scale longitudinal study of smokers carried out in London transport workers (fig. 4). This very simplified model illustrates two opposite groups of smokers, one susceptible to the effects of tobacco smoke, the other not susceptible and behaving just like those who have never smoked. By the way, these authors have suggested the outcome in $\mathrm{FEV}_{1}$ decline after stopping smoking. The variability in susceptibility could result from intervention of other risk factors, be it environmental or host factors. The latter include genetic determinants along with phenotypic susceptibility [31, 33-39]. Such host factors involvement comes from the familial clustering of patients with

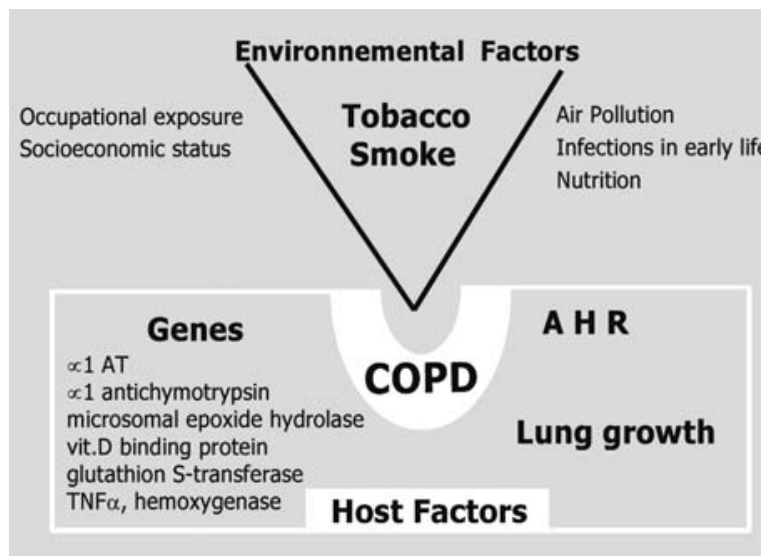

Fig. 3. - Tobacco is a major risk factor for COPD. 


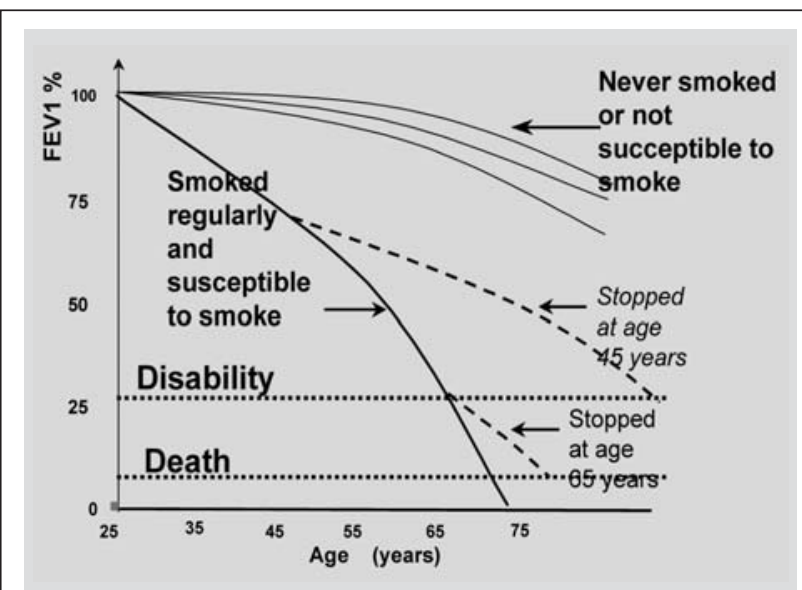

Fig. 4. - Model of longitudinal decline in $\mathrm{FEV}_{1}$ (modified from Fletcher 1977 ref. 11).

early-onset of COPD [33] as well as from differences in prevalence of COPD among different ethnic populations $[33,34,39,40]$. The genetic determinants of COPD are complex [31-38]. Many candidate genes potentially responsible for COPD were described (38): $\alpha 1$ antitrypsin gene ( $\alpha 1$ AT), $\alpha 1$ chymotrypsin genes, $\alpha 2$ macroglobulin genes, the vitamin $\mathrm{D}$ binding protein genes, and the blood-serotype group genes, cytochrome P450 A1, etc. Those involved in the pathogenesis of COPD are: extracellular superoxide dismutase, secretory leucocyte proteinase inhibitor, cathepsin G. However, only $\alpha 1$ AT deficiency, which is a monogenetic disease and represents less than $1 \%$ of patients with COPD, has been demonstrated to lead to early emphysema whose risk is increased by smoking (19). Moreover, the $\alpha 1$ AT gene is highly polymorphic with more than 75 different alleles, the more common variants being the alleles $\mathrm{M}, \mathrm{S}$, and $\mathrm{Z}$. The homozygous for the $\mathrm{Z}$ allele are more prone to develop a severe $\alpha 1$ AT deficiency. Among the association between different genotypes and the development of COPD, an MZ genotype is a higher risk factor than an MM genotype [41]. Besides, phenotypic traits such as gender, bronchial responsiveness, and atopy are considered relevant risk factors for the development of COPD $[19,42]$. The role of gender is controversial: the first studies suggested a greater COPD prevalence and mortality in men than in women, which may originate in not taking into account cigarette smoking and occupational exposure [20, 25, 43]. More recent studies suggested a higher female vulnerability to cigarette smoke [44-47], may be due to higher airway hyperresponsiveness in females [45]. The Lung Health Study [48] would tend to place males and females at the same level of susceptibility to the deleterious effects of cigarette smoking. The increasing rate of smoking among women particularly in developed countries and their taking up smoking at a younger age, herald a high toll in smoking morbidity and mortality among women over the coming decades [16]. Similarly, nutritional depletion [49] and low educational level [50], which are characteristic of low income countries, are correlated with the worst prognosis in COPD patients.
To conclude, active cigarette smoking accounts for most cases of COPD. The age of starting to smoke, total pack-years, and current smoking status are predictive of COPD mortality. But it is likely that there are important interactions between environmental factors and genetic predisposition to develop COPD, explaining a large heterogeneity in response to cigarette smoke.

\section{Could passive smoking lead to COPD?}

Environmental tobacco smoke (ETS) composition is qualitatively similar to mainstream smoke and causes inflammatory effects. Besides, as ETS persists for a long time after smoking, it interacts with other environmental pollutants.

\section{In children}

For certain, ETS is harmful particularly in early childhood [19, 51-62]. It is partly because a growing lung is vulnerable, and hazards in this phase of rapid alveolar development could be irreversible. Moreover, even intra-uterine exposure to smoke, causes smaller airways and alterations of both lung growth and maturation of the foetal lung. It leads to alteration of the immune system [53] and to decreases in lung function, not only just after birth and in the short-term [53-57], but also later on and throughout life $[58,59]$. In addition, a smoking mother exposes the new-born to a lower weigh which is a risk factor for infection and could pave the way for COPD development [53], all the more as cigarette smoke impairs the immune defence system. It is in line with the phenomenon of the "horse racing effect" of Fletcher, according to which individuals with a lower level of lung function had an accelerated decline demonstrated in studies such as: the East Boston Study [60] where $\mathrm{FEV}_{1}$ was reduced to $93 \%$ of the maximum rate over a 5 year period in exposed non-smoking school children aged 6-19 years. In the Harvard Six Cities Study [61] involving 8,706 children aged 6-9 years with a 12 year follow-up, a small but significant reduction of lung growth was found with an average of $-3.8 \mathrm{~mL} / \mathrm{yr}$ of $\mathrm{FEV}_{1},-14.3 \mathrm{~mL}$ /yr of mid expiratory flow rate MEF 25-75\%, 2.8 mL/yr of FVC in children aged 6-10 years, but not in older children. A recent metaanalysis of 21 cross-sectional studies in school children exposed to ETS found a decrease of $1.4 \%$ of FEV $1,5.0 \%$ of MEF $25-75 \%$ and $4.3 \%$ of end expiratory flow rate [62]. A recent study from 37 areas participating in the ECRHS [63], including interviews and questionnaires of 18,922 subjects aged 20-44 years from random population samples, showed the negative impact of intrauterine and environmental exposure to parental ETS, on the prevalence of respiratory symptoms, reduced $\mathrm{FEV}_{1}$ and increased airway obstruction. According to the authors, early exposure in life to tobacco smoke, may lead to airways structure changes during the maturation march, particularly during the foetal life in females, and during the postnatal life in males. The risk of developing COPD is greater in young 
adults previously exposed to parental cigarette smoke. But on the other hand, other longitudinal or cohort studies such as the Tuscon Study (64) found no adverse effect on lung function or lung growth in relation to ETS exposure.

\section{In adults}

Indeed, most studies have focused on the impact of ETS on wheezing, asthma, and low respiratory tract infection in childhood. Yet, the decrement in lung function, although small but significant, was observed in adolescents [61, 62] and adults [64]. Whether the lung impairments in early life due to smoke exposure could per se lead to COPD is still being questioned. In a recent general review by Jaakkola [52], the results of 15 crosssectional and two longitudinal studies related to home and workplace exposure to ETS and its lung function in adults, were inconsistent. Nevertheless, nine out of these studies showed a significant negative effect on $\mathrm{FEV}_{1}$ ranging from $50 \mathrm{~mL}$ in Singapore [65] to $257 \mathrm{~mL}$ in China [66]. None of the two longitudinal studies in adults, corroborated by other studies, demonstrated a significant decline in lung function over time. A more recent review by Jaakkola [67] has reported the impact of ETS on the development of or mortality from COPD. All three case-control and three longitudinal studies showed an increased risk in high ETS exposure categories. The excess risk was estimated to be from $60 \%$ to $>400 \%$. The estimated excess risk of developing COPD related to previous ETS exposure ranges from 30 to $>100 \%$ [52]. It is likely that the impact of ETS exposure on lung function in adults is dependent on many factors such as: duration and intensity of exposure [64], housing and workplace conditions which imply indoor and/or occupational pollutants, not to mention individual susceptibility. It is considered, by and large, that the impact of ETS exposure in adulthood on lung function is less harmful than in childhood. Studies directed on the effects of ETS exposure on the development of diagnosed COPD are limited and sometimes difficult to interpret. On six studies cited by Jaakkola [52], three included asthma in the definition of COPD because of the overlapping of the two disorders in adults. The higher risk for developing the condition was associated with cumulative ETS exposure in childhood and adulthood [68]. It is likely that the risk may increase with a higher level of exposure [69] and possibly with overt or other hidden environmental factors. On the other hand, latent adenal virus respiratory infection could favour the development of COPD [70].

\section{How does tobacco smoke cause COPD?}

As previously seen, cigarette smoke is by far the most important cause of COPD. COPD is defined as a chronic inflammation of the airways, including the parenchyma and the pulmonary vasculature. The master word in COPD mechanisms is a specific, persistent inflammation, different from that of asthma [1,37, 71-73] and associated with progressive, irreversible airway obstruction. Three other processes accompany and interact with inflammation: imbalance of both the proteases-antiproteases, the oxidants-antioxidants, and improper repair mechanisms [1, 37, 71] (fig. 5).

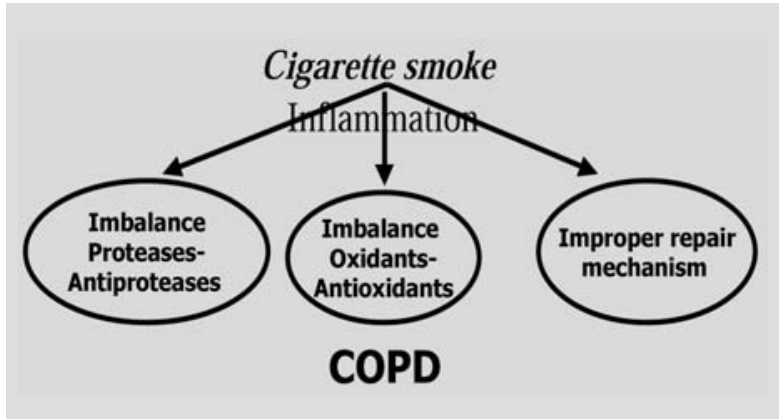

Fig. 5. - Pathogenesis and pathophysiology of COPD (mainly related to tobacco smoke).

\section{Inflammation}

Cigarette smoke, by virtue of the toxic and irritant effects of its numerous constituents, induces in the lung of humans and experimental animals an accumulation of inflammatory cells, which are recruited and activated. These cells release proteolytic enzymes, a source of lung tissue destruction. The damages include ciliotoxicity, mucus hypersecretion and matrix destruction. As evidenced in bronchioalveolar lavage (BAL), induced sputum or bronchial-biopsies in smokers with COPD, there is an increase in inflammatory cells, particularly neutrophils, macrophages, and T lymphocytes predominantly $\mathrm{CD} 8+\mathrm{T}$ cells (which are cytotoxic) [73-77]. Macrophages may play a critical role in the inflammatory process, not only in initiating but also in perpetuating the proteolytic activity in the lungs of patients with COPD / emphysema [73-76]. They are activated by cigarette smoke and other environmental irritants, releasing inflammatory mediators such as neutrophil-chemotactic factors, interleukin 8, leukotriene B4 which in turn promote neutrophilic inflammation. All these mediators have been found at a higher level in induced sputum of patients with COPD. Their levels are correlated with the disease severity [73, 78]. AM are recruited to the damage sites and are concentrated in large and small airways and the centroacinar zones where alveolar destruction is most marked [75]. The concentration of AM and T lymphocytes, but not neutrophils in the alveolar wall, are correlated with the degree of emphysema [75]. Tumor necrosis factor $\alpha$ is also increased in the sputum of COPD patients [73-75, 77, 80] and may activate the transcription of nuclear factor-Kb which switches on the transcription of the IL 8 gene in epithelial cells and macrophages [36, 79]. The increase of neutrophils is also a feature of COPD as demonstrated in sputum and BAL fluid of patients with COPD [73, 82, 83] where their concentration is higher than in smokers without COPD [73]. Their concentration is lower in bronchial-biopsies suggesting their rapid transit 
from the circulation into the airway luminen [71]. Neutrophil activation releases myeloperoxidase (MPO) and human neutrophil lipocalin present in great concentration in induced sputum [84]. Increased lymphocytes is found in the mucosa and the alveolar parenchyma [75-77], with T lymphocyte burden directly correlated with the severity of emphysema [75]. T cells may accelerate apoptosis and destruction of epithelial cells through the release of perforins and TNF- $\alpha$ [85]. The main inflammatory effects driven by inflammatory cells and their mediators are: squamous metaplasia of the epithelium with loss of cilia, mucus gland enlargement, thus hypersecretion and luminal obstruction, disrupted alveolar attachments and parenchymal destruction, mucosal oedema and peribronchial fibrosis. It is noteworthy that once initiated by cigarette smoke, the inflammatory process in the airways may persist even in healthy smokers as suggested by bronchial-biopsies [73, 83]. It persists albeit at a lesser level after quitting $[86,87]$. On the other hand, cigarette smoke drives a release of neuropeptides from the airway sensory nerves which exacerbate the bronchoconstriction [88].

\section{Imbalance proteases-antiproteases}

There is a complex interaction between the inflammatory cells and the proteolytic enzymes they release, and the proteases-antiproteases system (fig. 6). Alveolar macrophages orchestrate the production of proteases through their mediators, essentially: neutrophil chemotactic factors, TNF- $\alpha$, IL 8 and LT B4, which in turn activate neutrophil to do the same $[1,37]$. Whereas neutrophil elastase remains the major protease behind the emphysema in $\alpha 1$ AT deficiency, which represents only $<1 \%$ of COPD cases, other proteases are implicated in the destruction of lung parenchyma in smoking-related emphysema by degrading elastin and collagen [89]. They include neutrophil proteinase 3, neutrophil cathepsin G, cathepsin B, L, S, and K, re-

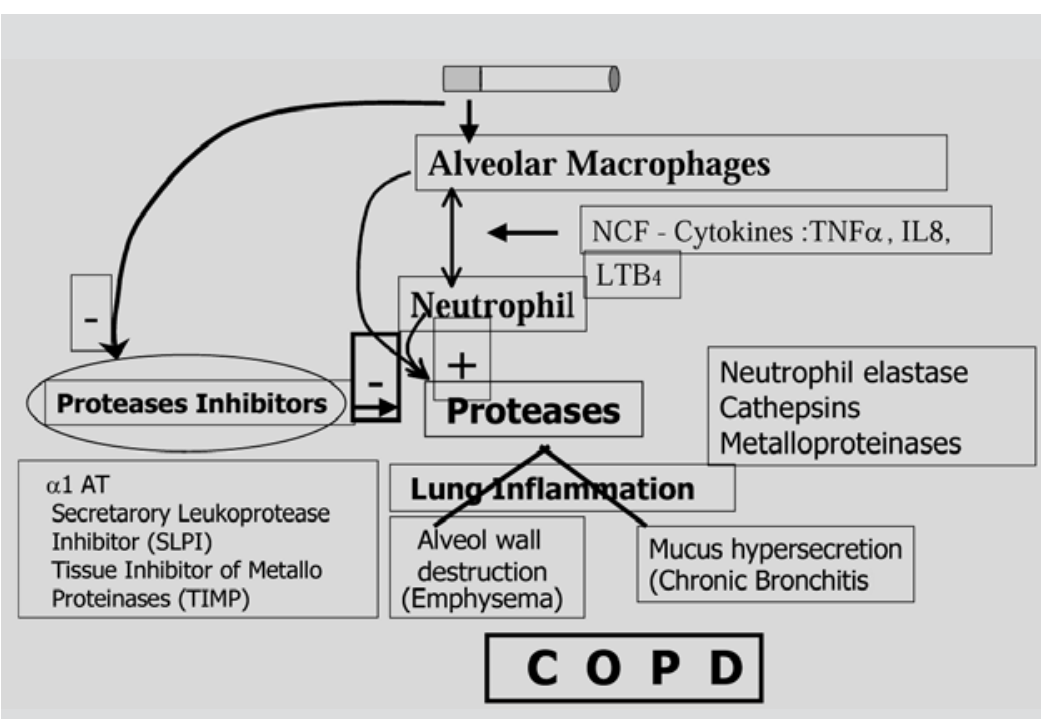

Fig. 6. - Imbalance of Proteases - Antiproteases. leased form AM, and various matrix metalloproteinases (MMP) derived from AM and neutrophils $[89,90]$. All these proteases have been found in high concentration in BAL fluid of patients with emphysema [90-93]. Besides, some proteases like neutrophil elastase, and protease 3 [94] induce mucus hypersecretion from goblet cells [95, 97]. In normal conditions, proteolytic enzymes are counteracted by endogenous antiproteases. In smokers without and notably with COPD [73, 93], there is excessive production and activity of proteases, and imperfect repair mechanism, probably due to the insufficient production or function of antiproteases $[71,97]$. The main proteases inhibitors are $\alpha 1 \mathrm{AT}$, secretory leucoproteases inhibitor (SLPI), tissue inhibitor of metalloproteases (TIMP-1, TIMP-2, and TIMP-3). It was suggested that variants in the TIMP-2 gene may predispose to COPD [98]. Amplification of the imbalance proteases-antiprotease driven by cigarette smoke may be exacerbated by latent adenal viral infection [70].

To sum up, cigarette smoke-related COPD causes neutrophilic and macrophagic inflammation of the lung which disrupt the proteases-antiproteases balance in favour of excessive production of proteases and defective production or function of endogenous antiproteases, leading to alveolar wall destruction and mucus hypersecretion [97].

\section{Imbalance oxidants-antioxidants}

High concentration of diverse oxidants are directly released in cigarette smoke [94] or secondarily formed by chemical processes during inhalation [96] (fig. 7). Each puff contains 1x1014_ 1016 of reactive free radicals present in both the tar and the gas phases of cigarette smoke $[99,100$, 103]. Besides, during cigarette smoking, reactive free radicals are released from neutrophils and AM migrated, sequestrated and activated in the microcirculation and the airspaces [37, 102]. Aggressive oxidants like superoxide $\left(\mathrm{O}^{2}-\right)$, superoxide dismutase (SOD), hydrogen peroxide $\left(\mathrm{H}_{2} \mathrm{O}_{2}\right)$, hydroxil radical $(-\mathrm{OH})$, myeloperoxidase (MPO), nitrosil (NO), etc. are produced [101, 102]. Many oxidants are found in high concentration in the breath of patients with stable COPD and during exacerbation [103], in the epithelial lining fluid and in the urine in cigarette smokers with or without COPD [104]. Besides, in a so-called "cooperative effect", the oxidative stress inactivates antiproteases (SLPI, $\alpha 1$ AT, TIMPs) [1, 98, 104, 105] and activates proteases. Whereas in normal conditions oxidants are fully counterbalanced by antioxidants, the oxidant injury induces a decrement in antioxidant capacity in stable COPD and much more during exacerbation. For instance there is a decrease in production or function of antioxidants like 


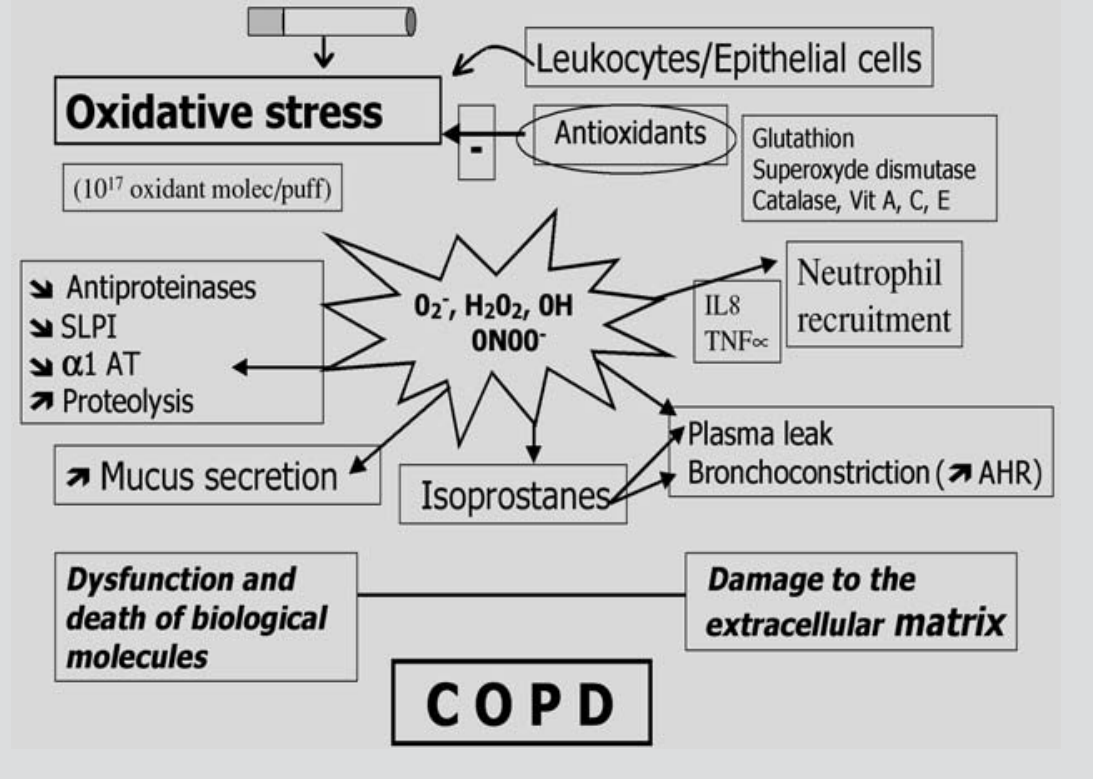

Fig. 7. - Imbalance of oxidases-antioxidases.

glutathion (GSH) [106-110] vit A, vit C, vit E [1, 102, 108, 111], betacarotene, selenium etc. [102]. This deleterious effect is partially prevented by GSH in concentrations $(500 \mu \mathrm{M})$ present in the epithelial lining fluid [105]. Hence, dietery deficiency could favour the development of COPD and antioxidants supplementation could be a possible preventive therapy against or at least could retard the development of COPD $[102,108]$. The oxidative stress also triggers gene expression of pro-inflammatory mediators such as IL 8, NO, and TNF$\alpha$ through transcription factor NF-kB, thus increasing the inflammatory process $[37,79]$. The imbalance oxidants-antioxidants contributes to a variety of damages, beginning with epithelium injury and increased epithelial permeability [101, 103] which occur at an early stage of cigarettesmoke exposure and paves the way for other damages. It provokes vascular tone dysfunction [112, 113], mucus hypersecretion, plasma leakage and bronchoconstriction (by increasing the airway hyperresponsiveness) [37, 114], destruction of cells and

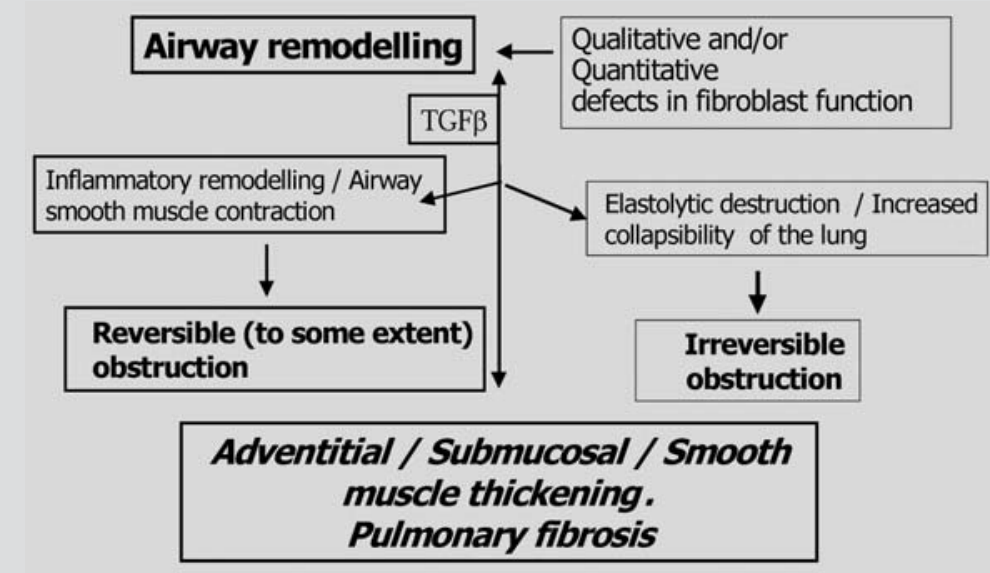

Fig. 8. - Improper repair mechanisms constituents of the extracellular matrix [1, 101, 111, 112].

\section{Improper repair mechanisms}

Inflammation initiated and perpetuated by cigarette smoke, leads per se and also through the imbalance of proteases-antiproteases and oxidants-antioxidants, to repeated cycles of injury and repair of the airways and parenchyma. It has been demonstrated that cigarette smoke particularly aldehyde and acrolein, reduces in a dose-dependent way, the migration and proliferation of human epithelial cells, as well as the production of fibronectin and tumor growth factor- $\beta$ (TGF- $\beta$ ). Cigarette smoking also impairs the capacity of the fibroblasts to contract collagen gels $[115,116]$. Incomplete repair process could lead to tissue remodelling, the main component of irreversible airway obstruction. It is due to qualitative and/or quantitative defects in fibroblast function, increased accumulation of collagen and scar tissue [116, 117] (fig. 8). Several mediators and particularly TGF- $\beta$ are involved in this process, provoking on the one hand elastolytic destruction, increased collapsibility of the lung and loss of elastic recoil [1, 117]. On the other hand, it provokes pulmonary arterial muscalarisation [1, 118, 119] with an increased amount of shortened and thickened smooth muscle, responsible for a greater degree of contraction and therefore a greater increase in airflow resistance. Oedema and proteoglycan and collagen accumulation increase submucosal and adventitial tissue. The reversible features of airway obstruction which could be targetted by therapy are, to some extent, airway smooth muscle contraction, accumulation of inflammatory cells, mucus and plasma exudates in the peripheral airways and the dynamic hyperinflation during exercise [97].

\section{Smoking and the course of lung funcion}

The course of lung function depends on factors operating in utero and early life during the growing period of lung, and also during adulthood [120, 121]. In normal conditions, lung function reaches its optimal value at 20-25 years of age, followed by a "plateau-phase" from 20 to 40 years, followed by a progressive decline [43, 120-124]. Many factors could predict separately or in combination, the devel- 
opment of COPD: a sub- optimal growth of the lung, a premature start of decline, and an accelerate decline in lung function [123]. Fletcher et al. [11] were the first to put forward the importance of the initial level of $\mathrm{FEV}_{1}$ as a predictor of decline in smokers. The phenomenon termed "the horse racing effect", means that individuals with lower level of lung function may have an accelerate decline in $\mathrm{FEV}_{1}$ [127]. As seen before, passive smoking could contribute to a decline in $\mathrm{FEV}_{1}$ of $5-7 \%$ in children by 14 years of age [128], essentially due to in utero exposure [54-59]. On the other hand, children and adolescents beginning to smoke at 15 years of age and continuing to smoke, would have $8 \%$ less of their expected $\mathrm{FEV}_{1}$ by 20 years of age [129]. The earlier the smoke exposure, be it passive or active, the greater the level of decline in lung function [2]. The natural history of the decline of $\mathrm{FEV}_{1}$ shows a large heterogeneity with rapid or progressive decline for some individuals whereas others have a nearly similar slow decline than healthy individuals over years of follow-up. There are models of longitudinal decline in $\mathrm{FEV}_{1}$ according to smoking or non-smoking conditions on the one hand, and within smokers according to their level of susceptibility to cigarette smoke on

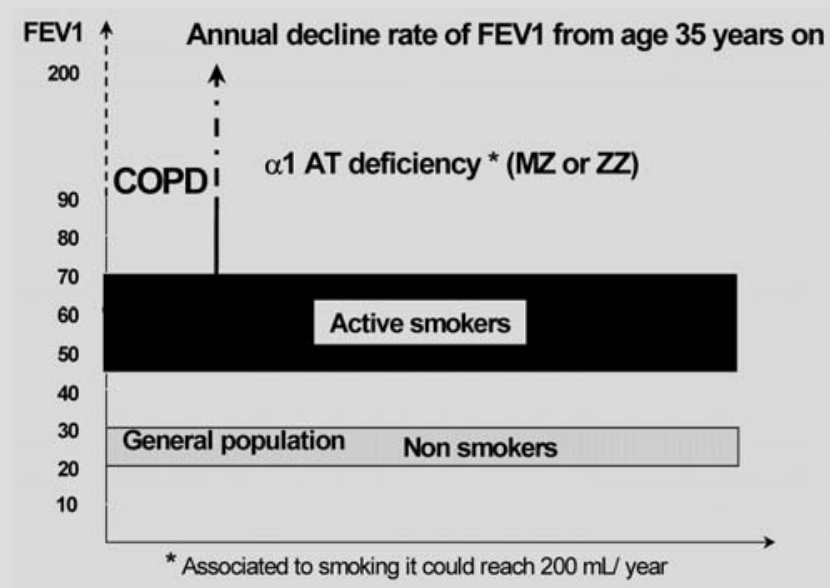

Fig. 9. - Active smoking \& lung function.

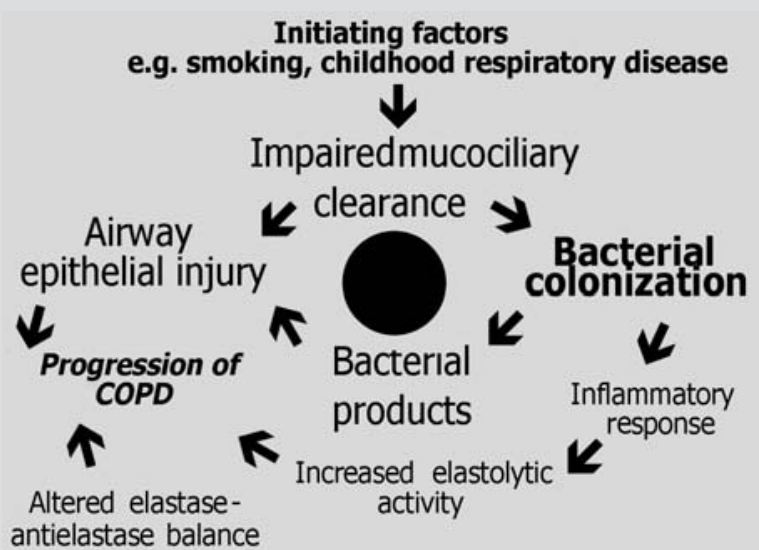

Fig. 10. - Vicious Circle Hypothesis. the other hand [11, 125-127]. It is considered according to these models, that from 25-30 years on, non-smokers in the general population lose $\mathrm{FEV}_{1}$ at a mean rate of 25-30 mL/year with age. Among smokers, those who are susceptible to cigarette smoke lose much more than non-smokers, 60 to $200 \mathrm{~mL} / y e a r$. The maximum decline was observed when $\alpha 1$ AT deficiency is associated. Non susceptible smokers have a FEV ${ }_{1}$ decline which could be either slightly more than those who never have smoked or a more pronounced decline but without COPD (fig. 9). Besides, airway responsiveness, independently from smoking condition, might play a role in the decline of $\mathrm{FEV}_{1}$ [120, 130], suggesting that high prevalence of airway responsiveness and the greater decline of $\mathrm{FEV}_{1}$ associated with it, should be considered as a high risk factor for the development of COPD particularly in smokers.

\section{Smoking and exacerbations of COPD}

In normal conditions, the tracheo-bronchial tree is sterile. Combined mucus hypersecretion, reduced clearance, and impairment of the lung defence mechanisms explain why COPD patients even with stable condition carry potential respiratory pathogens in significant concentration, paving the way for infection. Infection and air pollution are among the main risk factors for acute exacerbations of COPD (AECOPD) [131-133]. There is no surprise that active smoking induces more frequent exacerbations [131133] by enhancing the airway inflammation in an additive manner with inflammation caused by bacteria [134]. That is suggested by the positive correlation existing between the cumulative quantity of cigarettes smoked and the increase of neutrophils and inflammatory indices in BAL fluid [135]. Inflammatory indices increase also in bronchial biopsies or in sputum [136, 137] as well as markers of oxidative stress [138, 139]. In COPD patients followed after discharge, current smoking is among the most frequent factors of exacerbations ranking four $(26 \%)$, after lack of pulmonary rehabilitation $(86 \%)$, poor inhaled technique $(43 \%)$ and lack of influenza vaccine $(28 \%)$ [140]. Increased eosinophilic inflammation observed during exacerbation may result from cigarette smoke [141, 142]. It is directly correlated with concentration of neutrophils and inversely with $\mathrm{FEV}_{1}$. This may explain the beneficial therapeutic effect of systemic corticosteroid in AECOPD [143]. Chronic colonisation in COPD patients with poten- 
tial respiratory pathogens could trigger through release of bacterial products, perpetuated inflammatory response, and increased elastolytic reactivity, both susceptibility to cigarette smoke and acute exacerbation, leading in a vicious circle to deterioration of COPD [144] (fig. 10). The Lung Health Study had shown that in smokers followed up for 5 years and continuing to smoke, lung function is deteriorating more rapidly with a loss of $7 \mathrm{~mL}$ in $\mathrm{FEV}_{1}$ at every additional exacerbation when smokers experienced one lower respiratory illness a year, and a greater decline for more than one lower respiratory illness a year [145].

\section{Impact of smoking cessation on COPD}

It has been established that to date, smoking cessation is the most effective and in essence the only measure to slow down the progression of COPD [1,11]. Fletcher et al. [11] were amongst the first to have shown that the rate of decline of $\mathrm{FEV}_{1}$ becomes slower after smoking cessation and parallels the level of non-smokers. According to their model, in sustained quitters, regardless of their age and even with already impaired lung function, the decline of $\mathrm{FEV}_{1}$ is slower and the onset of disability and death is delayed. But the sooner, the better. Other longitudinal studies sum-

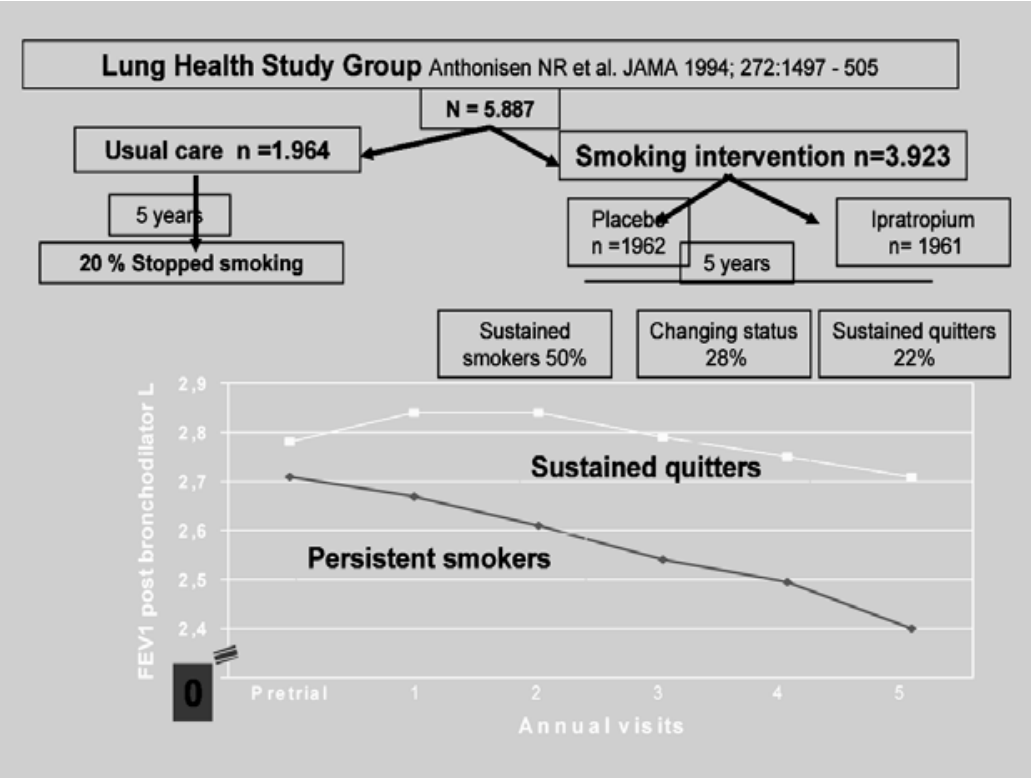

Fig. 11. - Impact of smoking cessation on the evaluation of COPD.

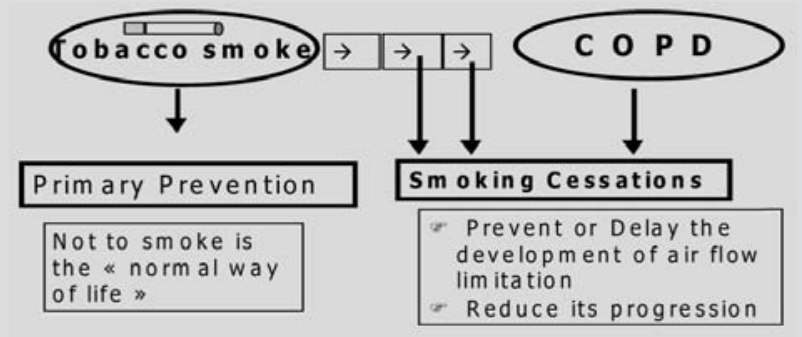

Fig. 12. - Stopping smoking helps at any time, the sooner the better. marised in the 1990 Surgeon Generals' Report on the health benefit of smoking cessation [18], followed by other recent studies [43, 146, 149], have confirmed this trend. For instance, a longitudinal study over a 6 year period on 4,451 men aged 45 to 68 , showed a steeper decline of $\mathrm{FEV}_{1}$ in inveterate smokers whereas it was lower and similar in those who had never smoked and those who had smoked in the past, at baseline. Moreover, the decline of $\mathrm{FEV}_{1}$ decreases in quitters during the first 2 years of follow up. However, symptoms persist several years after cessation when smoking starts at a younger age and when per day consumption is high, irrespective of gender [151]. On the other hand, benefits occur within a few years of smoking cessation as demonstrated in other studies [2, 48]. One of the most and prominent studies is the Lung Health Study which has demonstrated the possibility to reverse the decline in $\mathrm{FEV}_{1}$ with intensive intervention programme in smokers with early signs of airway obstruction and reduced expiratory flow, whereas improvement with bronchodilator was smaller, non-cumulative and reversed when the drug was discontinued [48] (fig. 11). Improvement in $\mathrm{FEV}_{1}$ during the first year was 2.5 times better in female than in male sustained quitters [151]. The earlier the quitting, the better the improvement in $\mathrm{FEV}_{1}$, once again, with better performance in female $(4.3 \%$ versus $1.2 \%$ in male) when quitting occurs at 20 years old. Conversely, one study has reported a better performance in male quitters aged 15-55 years with a greater reduction in $\mathrm{FEV}_{1}$ decline than in female: 20.6 $\mathrm{mL}$ versus $15.7 \mathrm{~mL}$, the discordance being explained by different statistical methods and by confounding factors such as indoor or outdoor environmental exposure [47]. Data from the Health Lung Study has also shown that the benefit of smoking cessation in smokers with mild-to-moderate lung function impairment significantly reduced the number of hospitalisations and mortality due to cardiovascular and coronary artery diseases [152]. Benefits from rehabilitation programmes in terms of improvement in quality of life have been evidenced by many studies summarised in the GOLD report [1]. Because rehabilitation programmes may give better benefits to quitters than sustained smokers [153] (Evidence B), involvement of COPD patients in smoking cessation is generally considered as a prerequisite to inclusion in rehabilitation programmes. Besides, one recent study has demonstrated an improvement in both direct and indirect airway hyperresponsiveness after one year smoking cessation 
without significant changes in lung function whereas inflammatory cell count in sputum increased [154]. But, given that quitting could be very difficult in heavy smokers, it was suggested that smoking reduction could help. In my opinion it could only be considered as a transcient step in the management of COPD, the ultimate objective remaining smoking cessation. Anyway, unassisted smoking reduction is not effective in terms of harm reduction according to a recent study. A reduction of more than half the number of cigarettes smoked per day, does not reduce cardiovascular nor smoking-related cancer mortality nor the risk of hospital admission for COPD in comparison with heavy smokers [155].

To conclude, as stated in the GOLD report: "Smoking cessation is the single effective and cost effective way to reduce exposure to COPD risk factors (Evidence A). Quitting smoking can prevent or delay the development of airflow limitation or reduce its progression" [1]. Stopping smoking helps at any time, the sooner the better (fig. 12). Rehabilitation is the gold standard of care for COPD patients. The main objectives of pulmonary rehabilitation are to reduce symptoms and disability, increase participation in physical and social activities and thus improve the overall quality of life, and finally reduce the management cost of the disease.

\section{References}

1. Global Initiative for Chronic Obstructive Disease. Global Strategy for The Diagnosis, Management, and Prevention of Chronic Obstructive Pulmonary Disease. NHLBI/WHO Workshop Report. National Institutes of Health, National Heart, Lung, and Blood Institute. Publication No. 2701, April 2001. Update of the management sections, GOLD web site www.goldcopd.com.

2. US Department of Health and Human Services. The health consequences of smoking: chronic obstructive lung disease. Washington DC, US Government Printing Office, 1984; D1-HIS (PHS) 84-50205.

3. Murray CJL, Lopez AD. Mortality by cause for eight regions of the world. Global burden of disease, 19902020. Nat Med 1998; 4: 1241-3.

4. Murray CJL, Lopez AD. Alternative projections of mortality and disability by cause, 1990-2020. Global Burden of Disease Study. Lancet 1997; 349: 1498-504.

5. Hurd S. The impact of COPD on lung health worldwide: epidemiology and incidence. Chest 2000; 117 (Suppl): $1 \mathrm{~S}-4 \mathrm{~S}$.

6. Sullivan SD, Ramsey SD, and Lee TA. The economic burden of COPD. Chest 2000; 117 (Suppl): 5S-9S.

7. World Health Organization. The World Health Report1999: making difference. Geneva, Switzerland: World Health Organization, 1990.

8. Murray CJL, Lopez AD, eds. The global burden of disease: a comprehensive assessment of mortality and disability from diseases, injuries, and risk factors in 1990 and projected to 2020. Cambridge, MA: Harvard University Press.1996.

9. Murray CJL, Lopez AD. Evidence-based health policylessons from the Global Burden of Disease Study. Science 1996; 274: 740-3.

10. Halbert RJ, Isonaka S, George D, Iqbal A. Interpreting COPD prevalence estimates: what is the true burden of disease? Chest 2003; 123: 1684-92.
11. Fletcher CM, Peto R. The natural history of chronic airflow obstruction. BMJ 1977; 1: 1645-8.

12. Menotti A, Blackburn $\mathrm{H}$, Seccariccia F, et al. The relation of chronic disease to all-cause mortality risk. The Seven Countries Study. Ann Med 1997; 29: 135-41.

13. Anthonisen NR. Prognosis in chronic obstructive pulmonary disease. Eur Respir Rev 1995; 5, 31: 310-4.

14. Bakke PS, Hanoa R, Gulsvik A. Educational level and obstructive lung disease given smoking habit and occupational airborne exposure: a Norvegian community study. Am J Epidemiol 1995; 141: 1080-8.

15. Prescott E, Lange P, Vestbo J, and the Copenhagen City Heart Study Group. Socieconomic status, lung function and admission to hospital for COPD: results from the Copenhagen City Heart Study. Eur Respir J 1999; 13: 1109-14.

16. Feenstra TL, van Genugten MLL, Hoogenveen RT, Wouters EF, and Rutten-van Molken MPMH. The impact of aging and smoking on the future burden of chronic obstructive pulmonary disease. A model analysis in the Netherlands. Am J Respir Crit Care Med 2001; 164: 590-6.

17. Aït Khaled N, Enarson D, Bousquet J. Chronic respiratory diseases in developing countries: the burden and strategies for prevention and management. Bull WHO 2001; 79 (10): 971-9.

18. US Department of Health and Human Services. The Health Benefits of Smoking Cessation. A report of the Surgeon General. US Government Printing Office, Washington, DC. 1990.

19. Buist AS. Risk factors for COPD. Eur Repir Rev 1996; 6,39: 253-8.

20. US Department of Health and Human Services. Reducing the consequences of smoking: 25 years of progress. A report of the Surgeon General. Rockville, MD, Department of Health and Human Services, Public Health Services, 1989.

21. Burrows B, Knudson RJ, Cline MG, Lebowitz MD. Quantitative relationship between cigarette smoking and ventilatory function. Am Rev Respir Dis 1977; 115: 195-205.

22. Holland WW. Chronic obstructive pulmonary disease prevention. Br J Dis Chest 1988; 82: 32-44.

23. Tashkin PD, Detels R, Simmons M, Liu H, and Coulson AH, Sayre J, Rokaw S.The UCLA population studies of chronic obstructive pulmonary disease: XI.Impact of air pollution and smoking on annual change in forced expiratory volume in one seconde. Am J Rerspir Crit Care Med 1994; 149: 1209-17.

24. Becklake MR, Lalloo U. The "healthy smoker": A phenomenon of health selection? Respiration 1990; 57: 137-44.

25. Xu X, Weiss ST, Rijcken B, Schouten JP. Smoking, changes in smoking habits, and rate of decline in $\mathrm{FEV}_{1}$ : new insight into gender differences. Eur Respir J 1994; 7: 1056-61.

26. Lange $\mathrm{P}$, Groth $\mathrm{S}$, Nyboe J, et al. Decline of the lung function related to the type of tobacco smoked and inhalation. Thorax 1990; 45: 22-6.

27. Turpin L, Earnest G, San Pedro M, Balmes JR, Eisner $\mathrm{MD}$, et al. The occupational burden of chronic obstructive pulmonary disease. Eur Respir J 2003; 22, 3: 462-9.

28. Becklake MR. Occupational exposures: evidence for a causal association with chronic obstructive pulmonary disease. Am Rev Respir Dis 1989; 140: S89-91.

29. Kauffman F, Drouet D, Lellouch J, Brille D. Twelve years spirometric changes among Paris area workers. Int J Epidemiol 1979; 8: 201-12.

30. Lebowitz MD. Epidemiologic studies of the respiratory effects of air pollution. Eur Respir J 1996; 9: 1029-54.

31. Bascom R. Differential susceptibility to tobacco smoke: possible mechanisms. Pharmacogenetics 1991; 1: 102-28. 
32. Lundback B, Lindberg A, Lindstrom M, et al. Not $15 \%$ but $50 \%$ of smokers develop COPD? Report from the obstructive lung disease in Northern Sweden studies. Respir Med 2003; 97: 115-22.

33. Silverman EK, Chapman HA, Drazen JM, et al. Genetic epidemiolgy of severe, early-onset chronic obstructive pulmonary disease: risk to relatives for airway obstruction and chronic bronchitis. Am J Respir Crit Care Med 1998; 157: 1770-8.

34. Silverman EK, Speizer FE. Risk factors for the development of chronic obstructive pulmonary disease. Med Clin North Am 1996; 80: 501-22.

35. Chen Y. Genetics and pulmonary medecine.10: Genetic epidemiology of pulmonary function. Thorax 1999; 54: 818-24.

36. Carrozi L, Rijcken B, Burney P, DeGraaf A, Angino A, et al. Family history for chronic lung diseases and epidemiological determinants of COPD in three European countries. Eur Respir Rev 2001; 11, 80: 49-54.

37. Barnes PJ. Chronic obstructive pulmoanry disease. $N$ Engl J Med 2000; 343, 4: 269-80.

38. Stanford AJ, Weir TD, Pare PD. Genetic risk factors for chronic obstructive pulmonary disease. Eur Respir $J$ 1997; 10: 1380-91.

39. Buist AS, Vollmer WM, Wu Y, et al. Effects of cigarette smoking on lung function in four population samples in the People's Republic of China. Am J Respir Crit Care Med 1995; 151: 1393-400.

40. Coultas DB, Gong H Jr, Grad R, et al. State of the art: respiratory disease in minorities of the United States. Am J Respir Crit Care Med 1993; 149: S93-131.

41. Tarjan E, Magyar P, Vaczi Z, Vaszar L. Longitudinal lung function study in heterozygous PiMZ phenotype subjects. Eur Respir J 1994; 7: 2199-204.

42. Antó JM, Vermeire P, Sunyer J. Chronic obstructive pulmonary disease. ERS Monograph edited by I. Annesi-Maesano, A. Gulsvik, G. Viegi: Respiratory Epidemiology in Europe 2000; 15, 5: 1-22.

43. Camilli AE, Burrows B, Knudson RJ, Lyle SK, Lebowitz MD. Longitudinal changes in forced expiratory volume in one second in adults: effects of smoking and smoking cessation. Am Rev Respir Dis 1987; 135: 794-9.

44. Prescott E, Bjerg AM, Andersen PK, Lange P, Vestbo J. Gender difference in smoking effects on lung function and risk for hospitalization for COPD. Results from a Danish longitudinal population study. Eur Respir J 1997; 10: 822-7.

45. Chen Y, Horn SL, Dosman JA. Increased susceptibility to lung dysfunction in female smokers. Am Rev Respir Dis 1991; 143: 1224-30.

46. Leynaert B, Bousquet J, Henry C, Liard R, Neukirch F. Is Bronchial hyperresponsiveness more frequent in women than in men? A population-based study. Am J Respir Crit Care Med 1997; 156: 1413-20.

47. Xu X, Li B, Wang L. Gender differences in smoking effects on adult pulmonary function. Eur Respir J 1994; 7: 477-83.

48. Anthonisen NR, Connett JE, Kiley JP, et al. Effects of smoking intervention and the use of an inhaled anticholinergic bronchodilator on the rate of decline of $\mathrm{FEV}_{1}$. The Lung Health Study. JAMA 1994; 272: 1497505.

49. Chailleux E, Laaban JP, Veale D. Prognostic value of nutritional depletion in patients with COPD treated by long-term oxygen therapy: data from the ANTADIR observatory. Chest 2003; 123: 1460-6.

50. Prescott E, Godtfredsen N, Vestbo J, Osler M. Social position and mortality from respiratory diseases in males and females. Eur Respir J 2003; 21: 821-6.

51. Buist AS, Connett JE, Miller RD, Kanner RE, Owens GR, Woelker HT. Chronic Obstructive Pulmonary Dis- ease Early Intervention Trial (Lung Health Study). Chest 1993; 103: 1863-72.

52. Jaakkola MS. Environmental tobacco smoke and respiratory diseases. ERS Monograph edited by I. AnnesiMaesano, A. Gulsvik, G. Viegi: Respiratory Epidemiology in Europe 2000, 15, 5: 322-83.

53. US Environmental Protection Agency. Respiratory health effects of passive smoking: lung cancer and other disorders. US Environmental Protection Agency, Office of Health and Environmental Assessment, Office of Research and Development. Washington DC, 1992. EPA/600/6-90/006F.

54. Lodrup Carlsen KC, Jaakkola JJK, Nafstad P, Carlsen $\mathrm{KH}$. In utero exposure to cigarette smoking influences lung function at birth. Eur Respir J 1997; 10: 1774-9.

55. von Ehrenstein OS, von Mutius E.S. Smoking and the lung. ERS Monograph edited by A. Bush, K-H. Carlson, M.S. Zach: Growing up with lung disease: the lung in transition to adult life 2001; 19, 7: 60-80.

56. Hanrahan JP, Tager IB, Segal MR, et al. The effect of maternal smoking during pregnancy on early infant lung function. Am Rev Respir Dis 1992; 145: 1129-35.

57. Tager IB, Ngo L, Hanrahan JP. Maternal smoking during pregnancy. Effects on lung function during the first 18 months of life. Am J Respir Crit Care Med 1995; 152: 977-83

58. Upton MN, Watt GC, Smith GD, McConnachie A, Hart CL. Permanent effects of maternal smoking on offsprings'lung function. Lancet 1998; 352: 453.

59. Strachan DP, Seagroatt V, Cook DG. Chest illness in infancy and chronic respiratory disease in later life: an analysis by month of birth. Int J Epidemiol 1994; 23: 1060-8.

60. Tager IB, Weiss ST, Munoz A, Rosner B, Speiser F. Longitudinal study of the effects of maternal smoking on pulmonary function in children. N Engl J Med 1983; 309: 699-703.

61. Wang X, Wypij D, Gold DR, et al. A longitudinal study of the effects of parental smoking on pulmonary function in children aged 6-18 years. Am J Respir Crit Care Med 1994; 149: 1420-5.

62. Cook DG, Strachen DP, Carey IM. Parental smoking and spirometric indices in children. Thorax 1998; 53: 844-93.

63. Svanes C, Omenaas E, Jarvis D, Chinn S, Gulsvik A, Burney P. Parental smoking in childhood and adult obstructive lung disease: results from the European Community Respiratory Health Survey. Thorax 2004; 59: 295-302.

64. Tager IB, Segal MR, Munoz A, Weiss ST, Speizer FE The effects of maternal smoking on the pulmonary function of children and adolescents. Analyses of data from two populations. Am Rev Respir Dis 1987; 136: 1366-70.

65. Ng TP, Hui KP, Wan C Tan. Respiratory symptoms and lung function effects of domestic exposure to tobacco smoke and cooking by gas in nonsmoking women in Singapore. J Epidemiol Commun Health 1993; 47: 454-9.

66. Wu X, Li B. Exposure-response relationship between passive smoking and adult pulmonary function. $A m J$ Respir Crit Care Med 1995; 151: 41-6.

67. Jaakkola MS. Environmental tobacco smoke and health in the elderly. Eur Respir J 2002; 19: 172-81.

68. Robins AS, Abbey DE, Lebowitz MD. Passive smoking and chronic respiratory symptoms in nonsmoking adults. Int J Epidemiol 1993; 22: 809-17.

69. Lee PN, Chamberlain J, Alderson MR. Relationship of passive smoking and lung cancer and other smoking-associated diseases. Br J Cancer 1986; 54: 97-105.

70. Matsuse T, Hayashi S, Kazuyoshi K, Keunecke H, Jefferies WA, Hogg JC. Latent adenal viral infection in the 
pathogenesis of chronic airways obstruction. Am Rev Respir Dis 1992; 146: 177-84.

71. Jeffery PK. Comparison of the structural and inflammatory features of COPD and asthma. Chest 2000; 117, 5: 251S-260S.

72. Barnes PJ. Mechanisms in COPD. Differences from asthma. Chest 2000; 117, 2 (Suppl): 10S-14S.

73. Keatings VM, Collins PD, Scott DM, Barnes PJ. Differences in interleukin- 8 and tumor necrosis factor- $\alpha$ induced sputum from patients with chronic obstructive pulmonary disease or asthma. Am J Respir Crit Care 1996; 153: 530-4.

74. Pesci A, Balbi B, Majori M, et al. Inflammatory cells and mediators in bronchial lavage of patients with chronic obstructive pulmonary disease. Eur Respir $J$ 1998; 12: 380-6.

75. Finkelstein R, Fraser RS, Ghezzo H, Cosio MG. Alveolar inflammation and its relation to emphysema in smokers. Am J Respir Crit Care Med 1995; 152: 1666-72.

76. O'Shaughnessy TC, Ansari TW, Barnes NC, Jeffery PK. Inflammation in bronchial biopsies of subjects with chronic bronchitis: inverse relationship of CD $8+\mathrm{T}$ lymphocytes with $\mathrm{FEV}_{1}$. Am J Respir Crit Care Med 1997; 155: 852-7.

77. Saetta M, Di Stephano A, Turato G, et al. CD 8+ T lymphocytes in peripheral airways of smokers with chronic obstructive pulmonary disease. Am J Respir Crit Care Med 1998; 157: 822-6.

78. Yamamoto C, Yoneda T, Yoshikawa M, et al. Airway inflammation in COPD assessed by sputum levels of interleukin-8. Chest 1997; 112: 505-10.

79. Barnes PJ, Karin M. Nuclear factor-kB: a pivotal transcription factor in chronic inflammatory diseases. $\mathrm{N} \mathrm{En-}$ gl J Med 1997; 336: 1066-71.

80. Hill AT, Bayley D, Stockley RA. The interrelationship of sputum inflammatory markers in patients with chronic bronchitis. Am J Respir Crit Care Med 1999; 160: 893-8.

81. Keatings VM, Barnes PJ. Comparison of inflammatory cytokines in chronic obstructive pulmonary diseases, asthma and controls. Eur Respir Rev 1997; 7: 146-50.

82. Pesci A, Majori M, Cuomo A, et al. Neutrophils infiltrating bronchial epithelium in chronic obstructive pulmonary disease. Respir Med 1998; 92: 863-70.

83. Peleman RA, Rytila PH, Kips JC, Joos GF, Pauwels RA. The cellular composition of induced sputum in chronic obstructive pulmonary disease. Eur Respir $J$ 1999; 13: 839-43.

84. Keatings VM, Barnes PJ. Granulocyte activation markers in induced sputum: comparison between chronic obstructive pulmonary disease, asthma, and normal subjects. Am J Respir Crit Care Med 1997; 155: 449-53.

85. Liu AN, Mohamed AZ, Rice WR, et al. Perforin-independent CD8(+) T cell-mediated cytotoxicity of alveolar epithelial cells is preferentially mediated by tumor necrosis factor-alpha: relative insensitivity to Fas ligand. Am J Respir Cell Mol Biol 1999; 20: 849-58.

86. Turato G, Di Stefano A, Maestrelli P, et al. Effect of smoking cessation on airway inflammation in chronic bronchitis. Am J Respir Crit Care Med 1995; 152: 1262-7.

87. Rutger SR, Postma DS, ten Hacken NH, et al. Ongoing airway inflammation in patients with COPD who do not currently smoke. Thorax 2000; 55: 12-8.

88. Chanez P, Springall D, Vignola AM, et al. Bronchial mucosal immunoreactivity of sensory neuropeptides in severe airway diseases. Am J Respir Crit Care Med 1998; 158: 985-90.

89. Shapiro SD. Elastolytic metalloproteinases produced by human mononuclear phagocytes. Potential role in destructive lung disease. Am J Respir Crit Care Med 1994; 150: S160-4.
90. Finlay GA, O'Driscoll LR, Russel KL, et al. Matrix metalloproteinase expression and production by alveolar macrophages in emphysema. Am J Respir Crit Care Med 1997; 156: 240-7.

91. Hoidal JR, Jeffery PK. Cellular and biochemical mechanisms in chronic obstructive pulmonary disease. ERS Monograph edited by D.S. Postma, N.M. Siafakas: Management of chronic obstructive pulmonary disease 1998, 7, 3: 84-91.

92. Betsuyaku T, Nishimura M, Takeyabu K, et al. Neutrophyl granule ptoteins in bronchoalveolar lavage fluid from subjects with subclinical emphysema. Am J Respir Crit Care Med 1999; 159: 1985-91

93. Culprit SV, Maziak W, Loukidis S, Nightingale JA Matthews JL, Barnes PJ. Effect of high dose inhaled steroid on cells, cytokines, and proteases in induced sputum in chronic obstructive pulmonary disease. Am J Respir Crit Care Med 1999; 160: 1635-9.

94. Witko-Sarsat V, Halbwachs-Mecarelli L, Schuster A, et al. Proteinase 3, a potent secretagogue in airways, is present in cystic fibrosis sputum. Am J Respir Cell Mol Biol 1999; 20: 729-36.

95. Saetta M, Turato G, Baraldo S, et al. Goblet cell hyperplasia and epithelial inflammation in peripheral airways of smokers with both symptoms of chronic bronchitis and chronic airflow limitation. Am J Respir Crit Care Med 2000; 161: 1016-21.

96. Nadel JA. Role of neutrophyl elastase in hypersecretion during COPD exacerbation, and proposed therapies. Chest 2000; 117: 386S-389S.

97. Suk B, Lutchen KR, Ingenito EP. On the progressive nature of emphysema. Role of proteases, inflammation, and mechanical forces. Am J Respir Crit Care Med 2003; 168: 516-21.

98. Hirano K, Sakamoto T, Uchida Y, et al. Tissue inhibito of metalloproteinases-2 gene polymorphisms in chronic obstructive pulmonary disease. Eur Respir J 2001; 18: 748-52.

99. Behr J, Nowak D. Tobacco smoke and respiratory disease. ERS Monograph edited by G. D'Amato and S.T. Holgate: The Impact of Air Pollution on Respiratory Health 2002; 21,7: 161-799.

100. Church DF, Pryor WA. Free-radical chemistery of cigarette smoke and its toxicological implications. Environ Health Perspect 1985; 64: 111-26.

101. Repine JE, Bast A, Lankhorst I, and the Oxidative Stress Study Group. Oxidative stress in chronic obstructive pulmonary disease. Am J Respir Crit Care Med 1997; 156: 341-57.

102. MacNee W. Oxidants-Antioxidants and COPD. Chest 2000; 117, 5: 303S-317.

103. Dekhuijzen PN, Aben KK, Dekker I, et al. Increased exhalation of hydrogen peroxide in patients with stable and unstable chronic obstructive pulmonary disease. Am J Respir Crit Care Med 1996; 154: 813-6.

104. Buhl R, Meyer A, Vogelmeier C. Oxidant-protease interaction in the lung. Prospects for antioxidant therapy. Chest 1996; 110: 267s-272s.

105. Mattana J, Margiloff L, Scharma P, Singal PC. Oxidation of the mesengial matrix metalloproteinase-2 impairs gelatinolytic activity. Inflammation 1998; 22: 269-97.

106. Lannan S, Donaldson K,Brown D, et al. Effects of cigarette smoke and its condensates on alveolar cell injury in vitro. Am J Physiol 1994; 266: L92-100.

107. Rahman I, Li WY, Donaldson K, et al. Cigarette smoke glutathione metabolism and epithelial permeability in rat lungs. Biochem Soc Trans 1995; 23: 235s.

108. Watchorn T, Mulier B, MacNee W. Does increasing intracellular glutathione inhibit cytoxine-induced nitric oxide release and NF-Kb activation. Am J Respir Crit Care Med 1998; 157: A889. 
109. Cantin AM, Begin R. Glutathione and inflammatory disorders of the lung. Lung 1991; 169: 123-38.

110. Rahman I, MacNee W. Oxidative stress and regulation of the glutathione in lung inflammation. Eur Respir $J$ 2000; 16: 535-54.

111. Mazzetti A, Lapenna D, Pierdominico SD, et al. Vitamins E, C, and lipid peroxidation in plasma and arterial tissue of smokers and nonsmokers. Atherosclerosis 1995; 112: 91-9.

112. Nishio E, Watanabe Y. Cigarette smoke extract is a modulator of mitogenic action in vascular smooth muscle cells. Life Sci 1998; 62: 1339-47.

113. Wright JL, Tai H, Dai J, Churg A. Cigarette smoke induces rapid changes in gene expression in pulmonary arteries. Lab Invest 2002; 82: 1391-8.

114. Rabe KF, Dent G, Magnussen H. Hydrogen peroxide contracts human airways in vitro: role of epithelium. Am J Physiol (Lung Cell Mol Physiol) 1995; 269: L332-8.

115. Wang H, Liu X, Umino T, Skold GM, Zhu Y, et al. Cigarette smoke inhibits human bronchial epithelial cell repair process. Am J Respir Cell Mol Biol 2001; 25: 772-9.

116. Carnevali S, Nakamora Y, MioT, et al. Cigarette smoke extract inhibits fibroblast-mediated collagen gel contraction. Am J Physiol 1998; 247-L591-8.

117. Rennard SI. Inflammation and repair process in chronic obstructive pulmonary disease. Am J Respir Crit Care Med 1999; 160-S12-6.

118. Peinado VI, Barbera JA, Abate $\mathrm{P}$, et al. Inflammation reaction in pulmonary muscular arteries of patients with mild chronic obstructive pulmonary disease. Am J Respir Crit Care Med 1999; 159: 1605-11.

119. Sekhon HS, Wright JL, Churg A. Cigarette smoke causes rapid cell proliferation in small airways and associated pulmonary arteries. Am J Physiol 1994; 267: L557-63.

120. Weiss ST. Early life predictors of adult chronic obstrucive pulmonary disease. Eur Respir Rev 1995; 5, 31: 303-9.

121. Tager IB, Segal MR, Speizer FE, Weiss ST. The natural history of forced expiratory volumes: effect of cigarette smoking and respiratory symptoms. Am Rev Respir Dis 1988; 138: 837-49.

122. Sherril DL, Camilli A, Lebowitz MD. On the temporal relationship between lung function and somatic growth. Am Rev Respir Dis 1989; 140: 638-44.

123. Rijcken B, Britton J. Epidemiolgy of chronic obstructive pulmonary disease. ERS Monograph edited by D.S. Postma, N.M. Siafakas: Management of chronic obstructive pulmonary disease 1998; 7, 3: 41-73.

124. Burrows B. Airway obstructive diseases: pathogenic mechanisms and natural histories of the disorders. Med Clin North Am 1990; 74: 547-60.

125. Burrows B. Predictors of loss of lung function and mortality in obstructive lung diseases. Eur Respir Rev 1991; 1: 340-5.

126. Postma DS, Vermeire P. The natural history of chronic obstructive pulmonary disease. ERS Monograph edited by D.S. Postma, N.M. Siafakas: Management of chronic obstructive pulmonary disease 1998; 7, 3: 74-83.

127. Burrows B, Knudson RJ, Camilli AE, Lyle SK, Lebowitz MD. The "horse racing effect" and predicting decline in forced expiratory volume in one second from screening spirometry. Am Rev Respir Dis 1987; 135: 788-93.

128. Tager IB, Weiss ST, Munoz A, Rosner B, Speizer F. Longitudinal study of the effects of maternal smoking on pulmonary function in children. N Engl J Med 1983; 309: 699-703.

129. Tager IB, Munoz A, Rosner B, Weiss ST, Carey V, Speirez FE. Effect of cigarette smoking on the pul- monary function of children and adolescents. Am J Respir Dis 19985; 131: 752-9.

130. Rijcken B, Schouten JP, Weiss ST, Speizer FE, Van derLende R. The relationship between airways responsiveness to histamine and pulmonary function level in a random population sample. Am Rev Respir Dis 1988; 137: 826-32.

131. Zalacain R, Sobradillo V, Amilibia J, et al. Predisposing factors to bacterial colonization in chronic obstructive pulmonary disease exacerbation. Eur Respir $J$ 1999; 13: 343-8.

132. Monso E, Rosell A, Bonet G, et al. Risk factors for lower airway bacterial colonization in chronic bronchitis. Eur Respir J 1999; 13: 338-42.

133. Miravittles M. Exacerbations of chronic obstructive pulmonary disease: when are bacteria important? Eur Respir J 2002, Suppl. 36: 9s-19s.

134. Mio T, Romberger DJ, Thompson AB, Robbins RA, Heires A, Rennard SI. Cigarette smoke induces interleukin-8 release from human bronchial epithelial cells. Am J Respir Crit Care Med 1997; 155: 1770-6.

135. Soler N, Ewig S, Torres A, Filella X, Gonzalez J, Xaubet A. Airway inflammation and microbial patterns in patients with stable chronic obstructive pulmonary disease. Eur Respir J 1999; 14: 1015-22.

136. Aaron SD, Angel JB, Lunau M, et al. Granulocyte inflammatory markers and airway infection during acute exacerbation of chronic obstructive pulmonary disease. Am J Respir Crit Care Med 2001; 163: 349-55.

137. Bhowmik A, Seemungal TA, Sapsford RJ, Wedzicha JA. Relation of sputum inflammatory markers to symptoms and lung function changes in COPD exacerbations. Thorax 2000; 55: 114-20.

138. Maziak W, Loukides S, Culprit S, Sullivan P, Kharitonov SA, Barnes PJ. Exhaled nitric oxide in chronic obstructive pulmonary disease. Am J Respir Crit Care Med 1998; 156: 998-1002.

139. Agusti AG, Villaverde JM, Togores B, Bosch M. Serial measurements of exhaled nitric oxide during exacerbations of chronic obstructive pulmonary disease. Eur Respir J 1999; 14: 523-8.

140. Garcia-Aymerich J, Barreiro E, Farrero E, Marrades RM, Morero J, Anto GM. Patients hospitalized for COPD have a high prevalence of modifiable risk factors for exacerbation (EFRAM study). Eur Respir J 2000; 16: $1037-42$.

141. Saetta M, Di Stefano A, Maestrelli P, et al. Airway eosinophilia in chronic bronchitis during exacerbations. Am J Respir Crit Care Med 1994; 150: 1646-52.

142. Saetta M, Di Stefano A, Maestrelli P, et al. Airway eosinophilia in and expression of interleukin-5 protein in asthma and in exacerbation of chronic bronchitis. Clin Exp Allergy 1996; 26: 766-74.

143. Niewoehner DE, Erbland ML, Deupree RH, et al. Effect of systemic glucocorticoids on exacerbations of chronic obstructive pulmonary disease. $N$ Engl J Med 1999; 340: 1941-7.

144. Sethi S. Bacterial infection and the pathogenesis of COPD. Chest 2000; 117: 286-91.

145. Kanner RE, Anthonisen NR, Connet JE. Lower respiratory illness promote $\mathrm{FEV}_{1}$ decline in current smokers but not ex-smokers with mild chronic obstructive pulmonary disease: results from the lung health study. $A m$ J Respir Crit Care Med 2001; 164: 358-64.

146. Peat JK, Woolcock AJ, and Cullen K. Decline of lung function and development of chronic airflow limitation: a longitudinal study of non-smokres and smokers in Busselton, Western Australia. Thorax 1989; 44: 31-7.

147. Townsend MC, DuChene AG, Morgan J, and Browner WS. Pulmonary function in relation to cigarette smoking and smoking cessation. Prev Med 1991; 20: 621-37.

148. Xu X, Dockery DW, Ware JH, Speizer FE, and Ferris 
BG Jr. Effects of cigarette smoking on rate of loss of pulmonary function in adults: a longitudinal assessment. Am Rev Respir Dis 1992; 146: 1345-8.

149. Burchfiel CM, Marcus EB, Curb JD, Maclean CJ, Vollmer WM, et al. Effects of smoking cessation on longitudinal decline in pulmonary function. Am $J$ Respir Crit Care Med 1995; 151: 1778-85.

150. Krzyzanowski M, Robbins DR, Lebowitz MD. Smoking cessation and changes in respiratory symptoms in two populations followed for 13 years. Int J Epidemiol 1993; 22: 666-73.

151. Scanlon PD, Connett JE, Walter LA, Altose MD, Bailey XC, Buist AS. Smoking cessation and lung function in mild-to-moderate chronic obstructive pulmonary disease. The Lung Health study. Am J Respir Crit Care Med 2000; 161: 381-90.

152. Anthonisen NR, Connett JE, Enright PL, Manfreda J, and the Lung Health Study. Hospitalizations and mortality in the Lung Health Study. Am J Respir Crit Care Med 2002; 166: 333-9.

153. Young P, Dewse M, Fergusson W, Kolbe J. Improvements in outcomes for chronic obstructive pulmonary disease (COPD) attributable to a hospital-based respiratory rehabilitation programme. Aust N Z J Med 1999; 29: 59-65.

154. Willemse BWM, ten Hacken NHT, Rutgers B, LesmanLeegle IGAT, Timens W, Postma DS. Smoking cessation improves direct and indirect airway hyperresponsiveness in COPD. Eur Respir J 2004, 24: 391-6.

155. Godtfredsen NS, Holst C, Prescott E, Vestbo J, Osler M. Smoking reduction, smoking cessation and mortality: a 16-year follow-up of 19, 732 men and women from the Copenhagen Centre for Prospective Study. Am J Epidemiol 2002; 156: 994-1001.

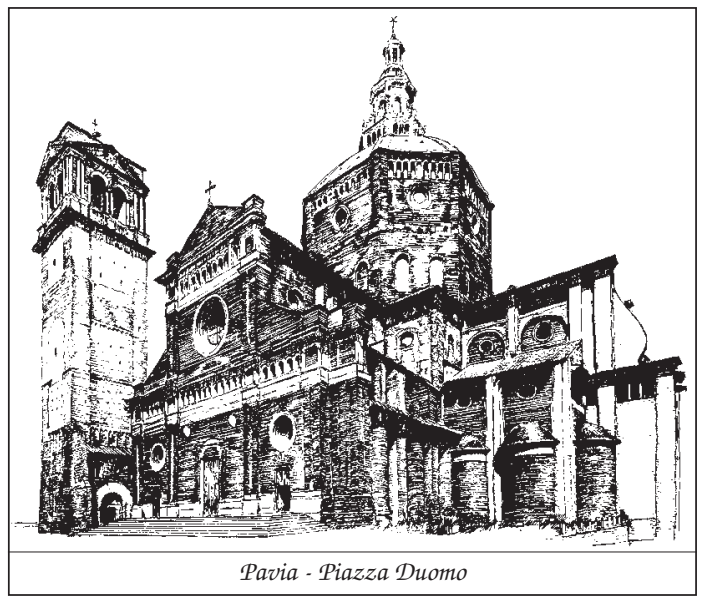

